\title{
Pro-apoptotic effect of the novel benzylidene derivative MHY695 in human colon cancer cells
}

\author{
GWANGBEOM HEO, DONGWAN KANG, CHAEUN PARK, SU JIN KIM, JIEUN CHOO, YUNNA LEE, \\ JIN-WOOK YOO, YUNJIN JUNG, JAEWON LEE, NAM DEUK KIM, HAE YOUNG CHUNG, \\ HYUNG RYONG MOON and EUNOK IM
}

College of Pharmacy, Pusan National University, Geumjeong-gu, Busan 46241, Republic of Korea

Received August 21, 2018; Accepted June 20, 2019

DOI: $10.3892 / 01.2019 .10664$

\begin{abstract}
The induction of apoptosis is a useful strategy in anti-cancer research. Various Moon Hyung Yang (MHY) compounds have been developed as novel anti-cancer drug candidates; in the present study, the pro-apoptotic effects of (Z)-5-(3-ethoxy-4-hydroxybenzylidene)-2-thioxothiazolidin-4-one (MHY695) on HCT116 human colon cancer cells were assessed. MTT assays were performed to investigate the dose-dependent cytotoxic effects of MHY695 on HCT116 cells. Immunofluorescence staining and flow cytometry analyses were performed to identify apoptotic cell death, and western blot analysis was used to investigate the apoptotic-signaling pathways. A mouse xenograft model was also used to determine the effects of MHY695 in vivo. MHY695 decreased the viability of HCT116 cells and induced apoptotic cytotoxicity. The apoptotic mechanisms induced by MHY695 involved the dephosphorylation of Bcl-2-associated agonist of cell death protein following protein kinase $B$ inactivation, induced myeloid leukaemia cell differentiation protein and $\mathrm{BH} 3$-interacting domain death agonist truncation, caspase- 3 and -9 activation and poly (ADP-ribose) polymerase cleavage. In addition, MHY695 significantly suppressed tumor growth in the mouse xenograft model, compared with the vehicle control. Notably, MHY695 exhibited potent anti-cancer effects in four different types of human colon cancer cell line, including Caco-2, DLD-1, HT-29 and HCT116. Additionally, MHY695 showed reduced cytotoxicity in NCM460, normal colonic epithelial cells. Furthermore, MHY-induced cytotoxicity in colon cancer cells was independent of the tumor suppressor protein p53. Collectively, these observations suggested that MHY695 may be a novel drug for the treatment of colon cancer.
\end{abstract}

Correspondence to: Dr Hyung Ryong Moon or Dr Eunok Im, College of Pharmacy, Pusan National University, 2, Busandaehak-ro, 63 Beon-gil, Geumjeong-gu, Busan 46241, Republic of Korea E-mail:mhr108@pusan.ac.kr

E-mail: eoim@pusan.ac.kr

Key words: colon cancer, apoptosis, caspase, poly(ADP-ribose) polymerase, p53

\section{Introduction}

Colon cancer is the third most frequently occurring cancer in the United States, following prostate cancer in males (or breast cancer in females) and lung cancer (1). In the Republic of Korea, colon cancer is the third most commonly diagnosed type of cancer, following thyroid and stomach cancer, and in 2014, the mortality rate of patients with colon cancer was the fourth highest of all cancer-associated deaths (2). Therefore, the development of novel anti-colorectal cancer drugs is urgently required. Numerous types of anti-cancer drug have been developed, and a select few, including 5-fluorourical (antimetabolite), oxaliplatin (a platinum-based antineoplastic), irinotecan (a topoisomerase inhibitor) and bevacizumab (a monoclonal antibody) are commercially available for the treatment of colon cancer. These drugs are used in different combinations and dosages depending on the cancer stage and condition of the patient (3)

Anti-cancer drugs exert their effects by inducing apoptosis in cancer cells. Apoptosis is a distinct form of programmed cell death and apoptotic cells possess certain characteristic features. Morphologically, apoptotic cells exhibit shrinkage, pyknosis and the formation of apoptotic bodies (4-6). Apoptosis incorporates a number of crucial biochemical steps. In the cytosol, BH3-interacting domain death agonist (Bid) becomes truncated and translocates to the mitochondria (7). In addition, the phosphorylation of Bcl-2-associated agonist of cell death (Bad) induced by phospho-protein kinase $B$ (p-Akt) is interrupted (8). Upon apoptotic signal transduction, cytochrome $\mathrm{C}$ is released from mitochondria, causing the activation of pro-caspase- 9 by forming an apoptosome with apoptotic protease-activating factor 1 . In turn, activated caspase- 9 is able to activate pro-caspase- 3 by proteolytic cleavage (9). During apoptosis, activated caspases promote the degradation or cleavage of diverse cytoskeletal and nuclear proteins, including poly(ADP-ribose) polymerase (PARP) (10).

Various MHY compounds that exert growth inhibitory effects against different types of cancer have previously been synthesized; these include the hydroxamic acid derivatives MHY218 and MHY219. MHY218 enhanced apoptotic cell death and exhibited anti-cancer activity in gastric, colon, breast and ovarian cancer. In the AGS human gastric cancer cell line, MHY218 inhibited autophagy and enhanced 
apoptotic cell death (11-14). MHY219, a novel histone deacetylase inhibitor, promoted the upregulation of androgen receptor expression levels, and induced apoptosis in human prostate cancer cells $(15,16)$. The oxirane derivatives MHY336, MHY407, MHY412 and MHY449 have also been investigated. MHY336, a novel epoxypropoxy flavonoid, induced apoptosis and cell cycle arrest in colon and prostate cancer cells by inhibiting topoisomerase II $(17,18)$. Additionally, the novel carbazole derivative MHY407 produced anti-cancerous effects in breast cancer cells by sensitizing the cells to doxorubicin-, etoposide- and radiation-induced DNA damage (19). The anthracene derivative MHY412 induced apoptosis in doxorubicin-resistant breast cancer cells by modulating cell cycle arrest and the downregulation of P-glycoprotein expression (20). Furthermore, MHY449, a novel dihydrobenzofuro[4,5-b][1,8]naphthyridine-6-one derivative, exerted potent anti-cancerous effects on prostate, gastric and lung cancer cells. Furthermore, in human lung cancer cells, MHY449 induced cell cycle arrest and apoptosis by inhibiting the activation of Akt (21-24). Further studies have also reported that benzylidene compounds exert anti-cancerous effects in various types of cancer cells by inducing apoptosis (25-27). Therefore in the present study, a novel benzylidene derivative, (Z)-5-(3-ethoxy-4-hydroxybenzylidene)-2-thioxothiazolidin-4-one (MHY695) was synthesized and investigated for cytotoxic effects in human colon cancer cells.

\section{Materials and methods}

Synthesis of MHY695. A suspension of 3-ethoxy-4-hydroxybenzaldehyde (purity, 99\%; $300 \mathrm{mg} ; 1.81 \mathrm{mmol}$; Sigma-Aldrich; Merck $\mathrm{KGaA}$ ) and rhodanine (purity, 97\%; 2-thioxothiazolidin-4-one; 264.5 mg; 1.99 mmol; Sigma-Aldrich; Merck $\mathrm{KGaA}$ ) in $4 \mathrm{ml}$ ethanol was refluxed for $5 \mathrm{~h}$ in the presence of piperidine (purity, 99\%; $0.05 \mathrm{ml} ; 0.54 \mathrm{mmol}$; Sigma-Aldrich; Merck KGaA) (28). After cooling to room temperature in the air, water $(20 \mathrm{ml})$ was added to the reaction mixture to induce precipitation. The precipitate was filtered and washed using water $(50 \mathrm{ml})$, ethyl acetate $(20 \mathrm{ml})$ and methylene chloride $(20 \mathrm{ml})$ and air-dried to yield MHY695 (purity, >98\%; $124.9 \mathrm{mg} ; 24.6 \%$ ) as an amorphous orange solid. Melting point, 207.8-210.1 ${ }^{\circ} \mathrm{C} ;{ }^{1} \mathrm{H}-\mathrm{NMR}\left(500 \mathrm{MHz}, \mathrm{DMSO}-d_{6}, \delta\right.$ in ppm): 13.70 (brs, 1H, NH), 10.02 (s, 1H, OH), 7.55 (s, 1H, vinylic H), 7.12 (d, 1H, $\left.J=2.0 \mathrm{~Hz}, 2^{\prime}-\mathrm{H}\right), 7.06$ (dd; $1 \mathrm{H} ; J=2.0,8.5 \mathrm{~Hz}$; 6'-H), 6.93 (d, 1H, J=8.5 Hz, 5'-H), 4.07 (q, 2H, J=7.0 Hz, 3'- $\mathrm{OCH}_{2}$ ), 1.35 $\left(\mathrm{t}, 3 \mathrm{H}, J=7.5 \mathrm{~Hz}, \mathrm{CH}_{2} \mathrm{CH}_{3}\right) ;{ }^{13} \mathrm{C}-\mathrm{NMR}$ (100 MHz, DMSO- $d_{6}$, $\delta$ in ppm): 196.1 (C2), 170.1 (C4), 150.9 (C3'), 147.9 (C4'), 133.5 (benzylic C), 125.8 (C6'), 125.0 (C1), 121.7 (C5), 117.1 (C5'), $116.1\left(\mathrm{C}^{\prime}\right), 64.6\left(3^{\prime}-\mathrm{OCH}_{2}\right), 15.3\left(\mathrm{CH}_{2} \mathrm{CH}_{3}\right)$; LRMS (ESI-) m/z $280(\mathrm{M}-\mathrm{H})^{-} ; \mathrm{HRMS}(\mathrm{ESI}) \mathrm{m} / \mathrm{z} \mathrm{C}_{12} \mathrm{H}_{11} \mathrm{NO}_{3} \mathrm{~S}_{2}(\mathrm{M}-\mathrm{H})^{-}$calculated mass: 280.0108; observed mass: 280.0122 .

To produce a stock solution, MHY695 was dissolved in DMSO to a concentration of $100 \mathrm{mM}$ (Fig. 1A). The solution was serially diluted in RPMI-1640 or DMEM/High glucose medium (HyClone; GE Healthcare Life Sciences) as required; the final DMSO concentration was $<0.1 \%$.

Cell culture. NCM460, a normal human colonic epithelial cell line, was obtained from INCELL Corporation LLC. The human colon cancer cell line HCT116 [p53 wild-type (wt)] was obtained from the Korea Cell Line Bank, and p53-null HCT116 cells were kindly provided by Dr Young-Chae Chang of the Department of Cell Biology, Catholic University of Daegu School of Medicine (Daegu, Republic of Korea). Human colon cancer DLD-1, Caco-2 and HT-29 cells were purchased from the American Type Tissue Culture Collection. The HCT116 and DLD-1 cells were cultured in RPMI-1640 medium supplemented with $10 \%$ fetal bovine serum (HyClone; GE Healthcare Life Sciences) and $1 \%$ penicillin/streptomycin (HyClone; GE Healthcare Life Sciences) at $37^{\circ} \mathrm{C}, 5 \% \mathrm{CO}_{2}$. NCM460, Caco-2 and HT-29 cells were cultured in DMEM/High glucose medium (HyClone; GE Healthcare Life Sciences) supplemented in the same manner as the RPMI-1640.

Cell viability assay. An MTT assay was performed to investigate the effects of MHY695 on the viabilities of NCM460, Caco-2, DLD-1, HT-29 and HCT116 cells. Thiazolyl blue tetrazolium bromide (Sigma-Aldrich; Merck KGaA) was dissolved in PBS to a stock concentration of $5 \mathrm{mg} / \mathrm{ml}$, and further diluted with RPMI-1640 or DMEM/High glucose medium to a working concentration of $0.5 \mathrm{mg} / \mathrm{ml}$. Cells were cultured in a 96 -well cell culture plate at a density of $5 \times 10^{3}$ cells/well for $24 \mathrm{~h}$ prior to treatment. The vehicle control $(0.05 \%$ DMSO in culture medium) or MHY695 samples were treated with 25 or $50 \mu \mathrm{M}$ in sextuplicate for $24 \mathrm{~h}$. Thiazolyl blue tetrazolium bromide $(0.5 \mathrm{mg} / \mathrm{ml})$ was subsequently added, and the cells were incubated in the dark for $2 \mathrm{~h}$. The formazan crystals were dissolved in DMSO and absorbance was measured at $540 \mathrm{~nm}$ using a microplate spectrophotometer (Thermo Fisher Scientific, Inc.). Each experiment was performed three times independently. The half maximal inhibitory concentration $\left(\mathrm{IC}_{50}\right)$ values were obtained using GraphPad Prism 5 (GraphPad Software).

Cytochrome $C$ and DAPI staining. HCT116 cells were cultured in 4-well chamber slides at a density of $5.0 \times 10^{4}$ cells/well for $24 \mathrm{~h}$, and treated with the vehicle or MHY695 $(25$ or $50 \mu \mathrm{M})$ for $24 \mathrm{~h}$ at $37^{\circ} \mathrm{C}$. The cells were fixed with $10 \%$ neutral-buffered formalin solution (Sigma-Aldrich; Merck KGaA) for $1 \mathrm{~h}$ at room temperature. The fixed cells were incubated in blocking/permeabilization solution, containing $0.1 \%$ triton-X-100 in protein block serum-free reagent (Dako; Agilent Technologies, Inc.) for $1 \mathrm{~h}$ at room temperature. The cells were subsequently incubated overnight with cytochrome $\mathrm{C}$ primary antibody (1:100; cat. no. sc-7159; Santa Cruz Biotechnology) at $4^{\circ} \mathrm{C}$. A goat anti-rabbit IgG, fluorescein isothiocyanate (FITC)-conjugated secondary antibody (1:200; cat. no. A120-101F; Bethyl Laboratories, Inc.) was added and incubated for a further $3 \mathrm{~h}$ in the dark at room temperature. Vectashield mounting medium with DAPI (Vector Laboratories, Inc.) was used for mounting, and the cells were washed with PBS between each step. Fluorescence was visualized using a confocal microscope at $\mathrm{x} 480$ magnification (Olympus).

FITC Annexin V staining. HCT116 cells were cultured in a 6-well culture plate at a density of $1 \times 10^{6}$ cells/well for $24 \mathrm{~h}$, and treated with the vehicle or MHY695 (25 or $50 \mu \mathrm{M})$ for $24 \mathrm{~h}$ at $37^{\circ} \mathrm{C}$. The treated cells were collected by centrifugation at $380 \mathrm{x} \mathrm{g}$ for $3 \mathrm{~min}$ at room temperature and stained using a FITC Annexin V Apoptosis Detection Kit I (BD Biosciences) 
A

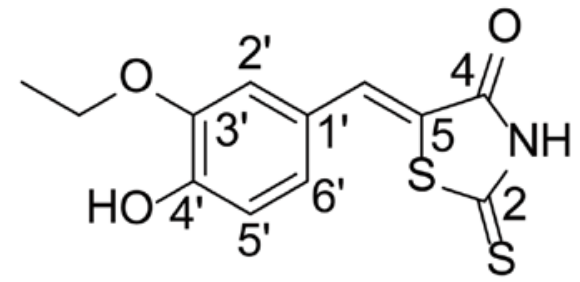

B

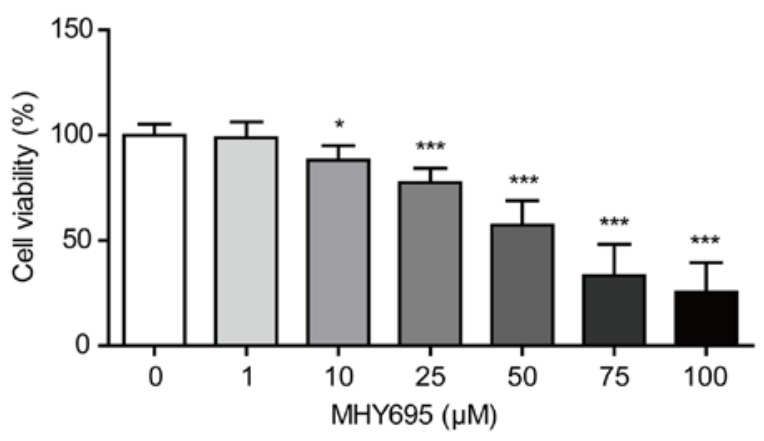

Figure 1. Viability of HCT116 cells investigated by MTT assay. (A) Structure of MHY695. (B) HCT116 cells were treated with vehicle or MHY695 for $24 \mathrm{~h}$ at the indicated concentrations. ${ }^{*} \mathrm{P}<0.05$ and ${ }^{* * * *} \mathrm{P}<0.001$ vs. the vehicle-treated group. MHY695, (Z)-5-(3-ethoxy-4-hydroxybenzylidene)-2thioxothiazolidin-4-one.

per the manufacturer's protocol. The stained cells were counted using a flow cytometer (BD Biosciences) within $1 \mathrm{~h}$, and the data were analyzed using C Flow Plus software (version 1.0.227.4; BD Biosciences).

Western blot analysis. HCT116 cells were cultured in a 6-well culture plate at a density of $1 \times 10^{6}$ cells/well for $24 \mathrm{~h}$, and treated with the vehicle or MHY695 ( 25 or $50 \mu \mathrm{M})$ for a further $24 \mathrm{~h}$ at $37^{\circ} \mathrm{C}$. The cells were harvested with cell scrapers and lysed in RIPA assay buffer (Elpis BioMed). The total protein was quantified using the Pierce ${ }^{\circledast}$ BCA Protein Assay Kit (Thermo Fisher Scientific, Inc.) and separated using SDS-PAGE on a 10 or $15 \%$ gel. The proteins were transferred to PVDF membranes (Merck KGaA) and incubated in 5\% bovine serum albumin, fraction V (cat. no. 160069; MP Biomedicals, LLC) or $5 \%$ non-fat dry milk (BD Difco ${ }^{\mathrm{TM}}$ ) for $1 \mathrm{~h}$. The membranes were subsequently incubated overnight at $4^{\circ} \mathrm{C}$ with the appropriate primary antibodies, diluted in blocking buffer. All of the primary antibodies were purchased from Cell Signaling Technology, with the exception of $\beta$-actin (Sigma-Aldrich; Merck KGaA). The catalog numbers and the dilution factors of the primary antibodies were as follows: p-Akt (Ser 473; 1:1,000; cat. no. \#9275), Akt (1:2,000; cat. no. \#9272), p-Bad (Ser136; 1:500; cat. no. \#4366), Bad (1:1,000; cat. no. \#9239), induced myeloid leukaemia cell differentiation protein (Mcl-1; 1:1,000; cat. no. \#5453), Bid (1:1,000; cat. no.\#2002), caspase-9 (1:1,000; cat. no.\#9508), cleaved caspase-9 (Asp330; 1:500; cat. no.\#9501), caspase-3 (1:1,000; cat.no.\#9662), cleaved caspase-3 (1:500; cat. no. \#9661), cleaved PARP (Asp214; 1:1,000; cat. no. \#9541), Bcl-2-binding component 3 (PUMA;1:1,000; cat. no. \#12450), Bcl-xL (1:1,000; cat. no. \#2764), Apoptosis regulator BAX (Bax; 1:1,000; cat. no. \#5023), Bcl-2 homologous antagonist/killer (Bak; 1:1,000; cat. no. \#12105) and $\beta$-actin
(1:10,000; cat. no. \#A5316). The membranes were washed using TBS-T buffer (10 mM Tris, $150 \mathrm{mM} \mathrm{NaCl}, \mathrm{pH} 8.0$, $0.2 \%$ Tween-20) after each step. The secondary antibodies were also diluted in blocking buffer and added for $2 \mathrm{~h}$ at room temperature. HRP conjugated goat anti-rabbit IgG polyclonal antibody (1:5,000; cat. no. ADI-SAB-300-J) and HRP conjugated goat anti-mouse IgG polyclonal antibody $(1: 20,000$; cat no. ADI-SAB-100-J) were purchased from Enzo Life Sciences Inc.. The blots were visualized using an enhanced chemiluminescence solution (Advansta Inc.) and the ChemiDoc ${ }^{\mathrm{TM}}$ Touch Gel Imaging System (Bio-Rad Laboratories, Inc.).

Mouse xenograft model. A total of 20 female BALB/c nude mice (four weeks of age) were obtained from OrientBio, Inc. The mice were housed under a $12 \mathrm{~h}$ light/dark cycle and fed rodent chow (Samtako Bio Korea) and tap water ad libitum. After a 1-week acclimation period, the mice were subcutaneously inoculated

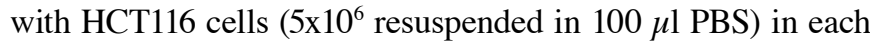
flank. After 1 week, vehicle solution or MHY695 (2 mg/kg diluted in PBS) was subcutaneously injected near the inoculated tumor site once a day. No animal exhibited signs of toxicity following the administration of MHY695. All inoculations were performed under anesthesia with isoflurane (Hana Pharm Co., Ltd) using the Small Animal $\mathrm{O}_{2}$ Single Flow Anesthesia System for Rat, Mouse (LMS Co., Ltd). The concentration of isoflurane was $3 \%$ for induction and $2 \%$ for maintenance, with $11 / \mathrm{min}$ oxygen. Inoculations were performed when the mice didn't respond to physical stimuli when under anesthesia. The diameter of each tumor was measured daily and tumor volume $\left(\mathrm{mm}^{3}\right)$ was calculated as (long diameter) ${ }^{2} \mathrm{x}$ (short diameter) $\mathrm{x} 0.5$. The mice were euthanized using carbon dioxide $\left(\mathrm{CO}_{2}\right.$; with a flow rate $20 \%$ per $\mathrm{min}$ ) and the tumor was dissected following the 12th injection of vehicle solution or MHY695. All animal research and protocols were reviewed and approved by the Pusan National University Institutional Animal Care and Use Committee (PNU-IACUC).

In vivo fluorescence imaging. GFP vectors, kindly provided by Dr Bum-Joon Park (Department of Molecular Biology, College of Natural Science, Pusan National University, Busan, Republic of Korea), were transfected into HCT116 colon cancer cells using the Lipofectamine ${ }^{\circledR} 3000$ transfection kit (Invitrogen; Thermo Fisher Scientific, Inc.) and Opti-MEM medium (Thermo Fisher Scientific). A total of 4 female $\mathrm{BALB} / \mathrm{c}$ nude mice (four weeks of age) were obtained from OrientBio, Inc., and acclimated for one week. The GFP-tagged HCT116 cells $\left(1.5 \times 10^{7}\right.$ cells resuspended in $100 \mu 1$ PBS) were inoculated subcutaneously into the flanks of each mouse. The vehicle or MHY695 (5 mg/kg diluted in PBS) was administered subcutaneously once a day near each tumor. Tumor fluorescence was observed daily using a fluorescence-labeled Organism Bioimaging Instrument (NeoScience Co., Ltd.) After the 4th injection of vehicle or MHY695, the mice were sacrificed using $\mathrm{CO}_{2}$ inhalation and the tumors were dissected for analysis.

Statistical analysis. Statistical analysis was conducted using GraphPad Prism 5 (GraphPad Software, Inc.). The data were analyzed using one-way analysis of variance followed by Tukey's test for multiple comparisons. The Student's t-test was performed for the comparison of two groups. The results are 
A

MHY695 ( $\mu \mathrm{M})$

DAPI

Cytochrome C
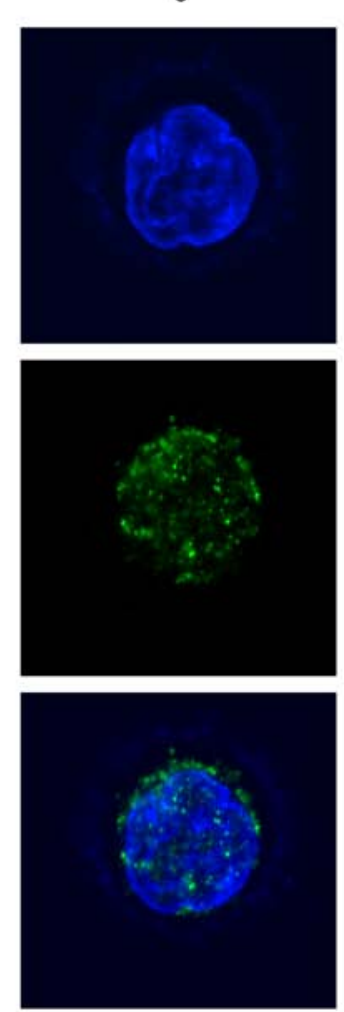

25
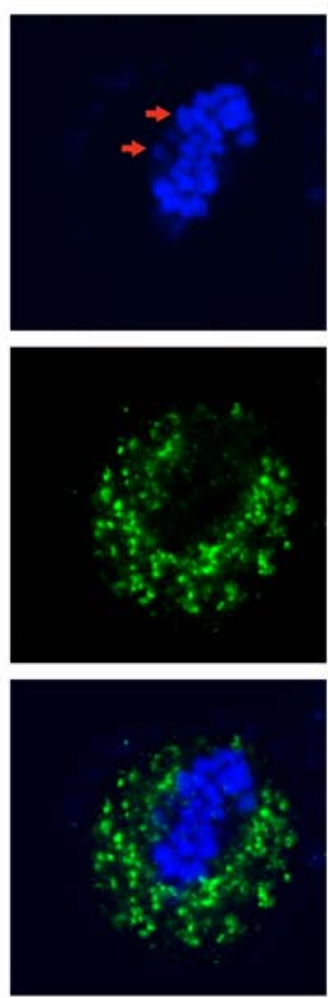

50
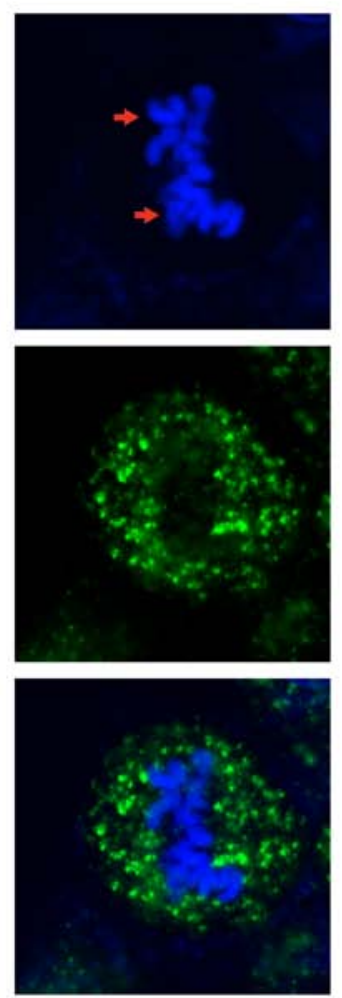

\section{B}

MHY695 ( $\mu$ M)

0

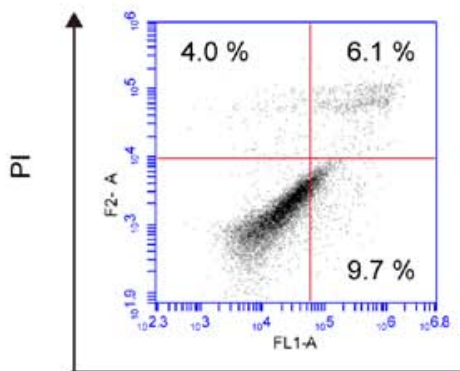

25

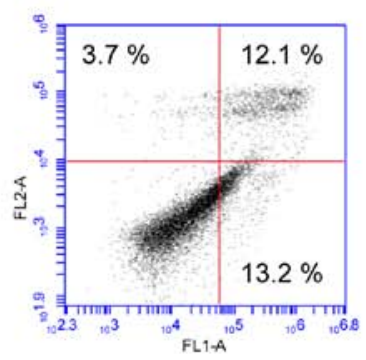

50

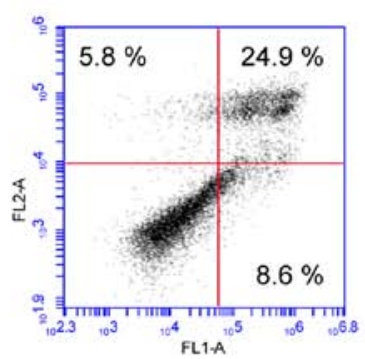

Annexin V

Figure 2. MHY695 induces cytotoxicity by promoting apoptosis. (A) Morphological changes in HCT116 colon cancer cells were observed by confocal microscopy. Cells were treated with vehicle or MHY695 (25 or $50 \mu \mathrm{M})$ for $24 \mathrm{~h}$. Apoptotic body formation (red arrows) was observed using DAPI staining (blue) in the MHY695-treated groups. The release of cytochrome C (green) was also observed in the MHY695-treated groups. (B) Apoptotic or necrotic cells were identified using flow cytometry. HCT116 cells were treated with MHY695 or vehicle for 24 h, prior to staining with Annexin V and PI. Annexin V-bound or PI-positive cells were subsequently quantified. MHY695, (Z)-5-(3-ethoxy-4-hydroxybenzylidene)-2-thioxothiazolidin-4-one; PI, propidium iodide.

expressed as the mean \pm standard deviation, and $\mathrm{P}<0.05$ was considered to indicate a statistically significant difference.

\section{Results}

MHY695 decreases cell viability of HCT116 human colon cancer cells. To investigate the effects of MHY695 on the viability of colon cancer cells, MTT assays were performed using the HCT116 human colon cancer cell line. HCT116 cells were treated with various concentrations of MHY695 for $24 \mathrm{~h}$, and cell viability was determined using an MTT assay. As shown in Fig. 1B, MHY695 significantly reduced the viability of HCT116 cells in a concentration-dependent manner. The percentages of viable cells were 98.8, 88.2, 77.4, 57.3, 33.4 and $25.5 \%$ following treatment with $1,10,25,50,75$ and $100 \mu \mathrm{M}$ MHY695, respectively.

MHY695 induces apoptotic cell death in HCT116 human colon cancer cells. To determine whether MHY695-induced cytotoxicity was the result of apoptotic cell death, nuclear morphological alterations were observed using DAPI staining. Confocal microscopic analysis of HCT116 cells treated with MHY695 (25 or $50 \mu \mathrm{M})$ for $24 \mathrm{~h}$ showed cellular shrinkage, nuclear condensation and the formation of apoptotic bodies. Moreover, cytochrome $\mathrm{C}$ release from the mitochondria into the cytosol was also observed in MHY695-treated HCT116 


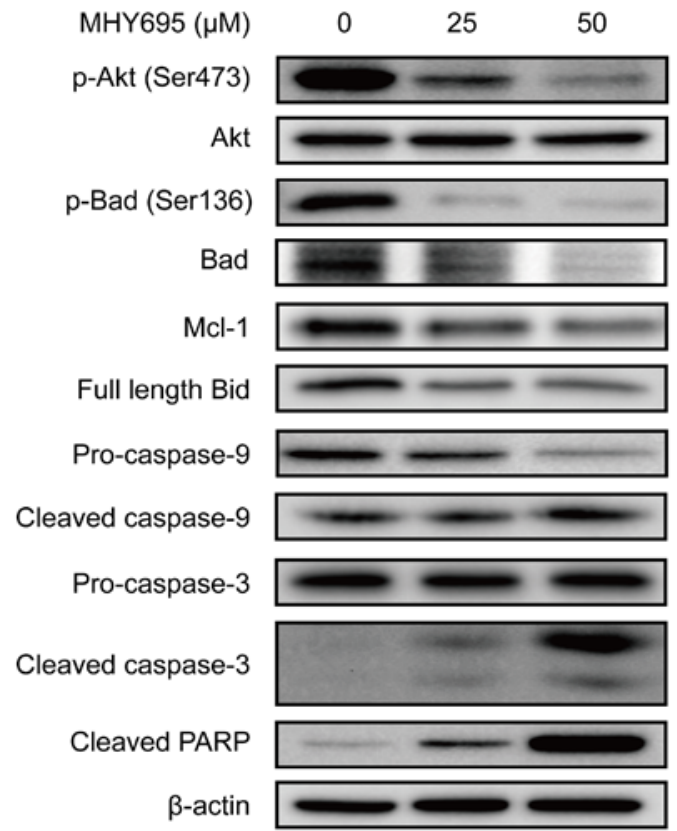

Figure 3. MHY695 modulates the expression of apoptosis-associated proteins. HCT116 cells were treated with vehicle or MHY695 $(25$ or $50 \mu \mathrm{M})$ for $24 \mathrm{~h}$. Cellular proteins were separated using SDS-PAGE and transferred to PVDF membranes. The bands were detected using ECL solution and a chemiluminescence system. The bands are representative of three independent experiments. MHY695, (Z)-5-(3-ethoxy-4-hydroxybenzylidene)-2thioxothiazolidin-4-one; p-, phospho-; Akt, protein kinase B; Bad Bcl-2-associated agonist of cell death; Mcl-1, induced myeloid leukaemia cell differentiation protein; PARP, poly(ADP-ribose) polymerase.

cells (Fig. 2A). To further investigate MHY695-induced apoptotic cell death, flow cytometric analysis of HCT116 cells treated with MHY695 was conducted after Annexin V/PI staining. As shown in Fig. 2B, the number of apoptotic cells increased in a concentration-dependent manner following MHY695 treatment. The percentages of early and late apoptotic cells (quadrants IV and I, respectively) were 15.8, 25.3 and $33.5 \%$ following treatment with MHY695 at 0,25 and $50 \mu \mathrm{M}$, respectively. In addition, the percentages of MHY695-induced cytotoxicity appeared to be higher in the MTT assays (Fig. 1B) compared with the Annexin V/PI assays (Fig. 2B), suggesting that MHY695 may also induce cell cycle arrest.

MHY695 modulates the expression of apoptosis-related proteins. To elucidate the apoptotic signal transduction induced by MHY695 in HCT116 cells, the expression levels of apoptosis-associated proteins were analyzed by western blot analysis. As shown in Fig. 3, Akt and Bad phosphorylation was inhibited by MHY695 treatment at 25 and $50 \mu \mathrm{M}$ for $24 \mathrm{~h}$. Mcl-1 expression was also inhibited by MHY695. The expression of full-length Bid was also decreased, suggesting that Bid truncation was increased by MHY695. As a result, caspase-9, caspase-3 and PARP cleavage was increased in a concentration-dependent manner.

MHY695 suppresses tumor growth in a mouse xenograft model. To investigate the anti-cancerous effects of MHY695 in vivo, a mouse xenograft model was employed. HCT116 cells were implanted into the left and right flanks of BALB/c nude mice; 1 week after cancer cell inoculation, the vehicle or MHY695 $(2 \mathrm{mg} / \mathrm{kg})$ were injected subcutaneously next to each tumor on a daily basis. As shown in Fig. 4A and B, MHY695 significantly suppressed tumor growth compared with vehicle. Although tumor volume was increased in both the vehicle and MHY695 groups, the growth rate of the MHY695-treated group was significantly lower than that of the vehicle group. As illustrated in Fig. 4C, tumor weight was also lower in the MHY695-treated group compared with the vehicle-treated group. Furthermore, xenograft tumors were visualized using an in vivo fluorescence imaging system, which revealed that four days after treatment, $5 \mathrm{mg} / \mathrm{kg}$ MHY695 resulted in reduced tumor growth compared with the vehicle (Fig. 4D).

Cytotoxic effect of MHY695 is independent of p53. To further investigate the cytotoxic effects of MHY695, a normal colon epithelial cell line and additional human colon cancer cell lines with different genetic features were employed. MTT assays were performed in NCM460, Caco-2, DLD-1, HT-29 and HCT116 cells. Fig. 5A illustrates that concentrations of MHY695 $\leq 50 \mu \mathrm{M}$ had no cytotoxic effect on NCM460 or HT-29 cells, while $50 \mu \mathrm{M}$ was able to reduce the viability of the other human colon cancer cell lines. Specifically, MHY695 showed significant inhibitory effects towards HCT116 cells at a concentration of $10 \mu \mathrm{M}$. In addition, the lowest $\mathrm{IC}_{50}$ value among the five cell lines was observed in HCT116 cells (Table I). Moreover, the expression levels of apoptosis-associated proteins were analyzed using western blotting. Fig. 5B illustrates that in DLD-1 cells, Akt phosphorylation (Ser473) was inhibited, but PARP cleavage was increased by 25 or $50 \mu \mathrm{M}$ MHY695 after $24 \mathrm{~h}$. However, Akt phosphorylation and PARP cleavage were not altered by MHY695 treatment in Caco-2, HT-29 and NCM460 cells, suggesting that these effects are cell type-specific.

It is well known that the p53 gene is mutated or deleted in the majority of cancer cell types. Therefore, the p53 status of the cells was also determined to elucidate the different cytotoxic effects. As shown in Table II, the p53 gene is mutated in Caco-2, DLD-1 and HT-29 cells, but HCT116 cells express wild-type p53 (29). Based on these findings, the cytotoxic effects of MHY695 on p53 wt and p53 null HCT116 cells were investigated using an MTT assay. As shown in Fig. 5C, the cytotoxic effect of MHY695 did not differ between p53 wt and p53 null HCT116 cells. Moreover, the expression levels of PUMA, Bcl-xL, Bax and Bak, downstream proteins of the p53-related apoptosis pathway, were not altered by MHY695 treatment, suggesting that MHY695-mediated cytotoxicity was independent of p53 (Fig. 5D).

\section{Discussion}

In the present study, MHY695 was demonstrated to induce cytotoxicity and apoptosis in HCT116 colon cancer cells. When used to treat various colon cancer cell lines, including Caco-2, DLD-1, HT-29 and HCT116 cells, MHY695 showed the greatest potency towards HCT116 cells. In an attempt to establish the reason for this finding, the mutation status of the p53 gene was investigated. The tumor suppressor protein p53 is a transcription factor that serves a pivotal role in apoptosis and cell cycle arrest. When p53 is mutated, cancer cells exhibit 
A
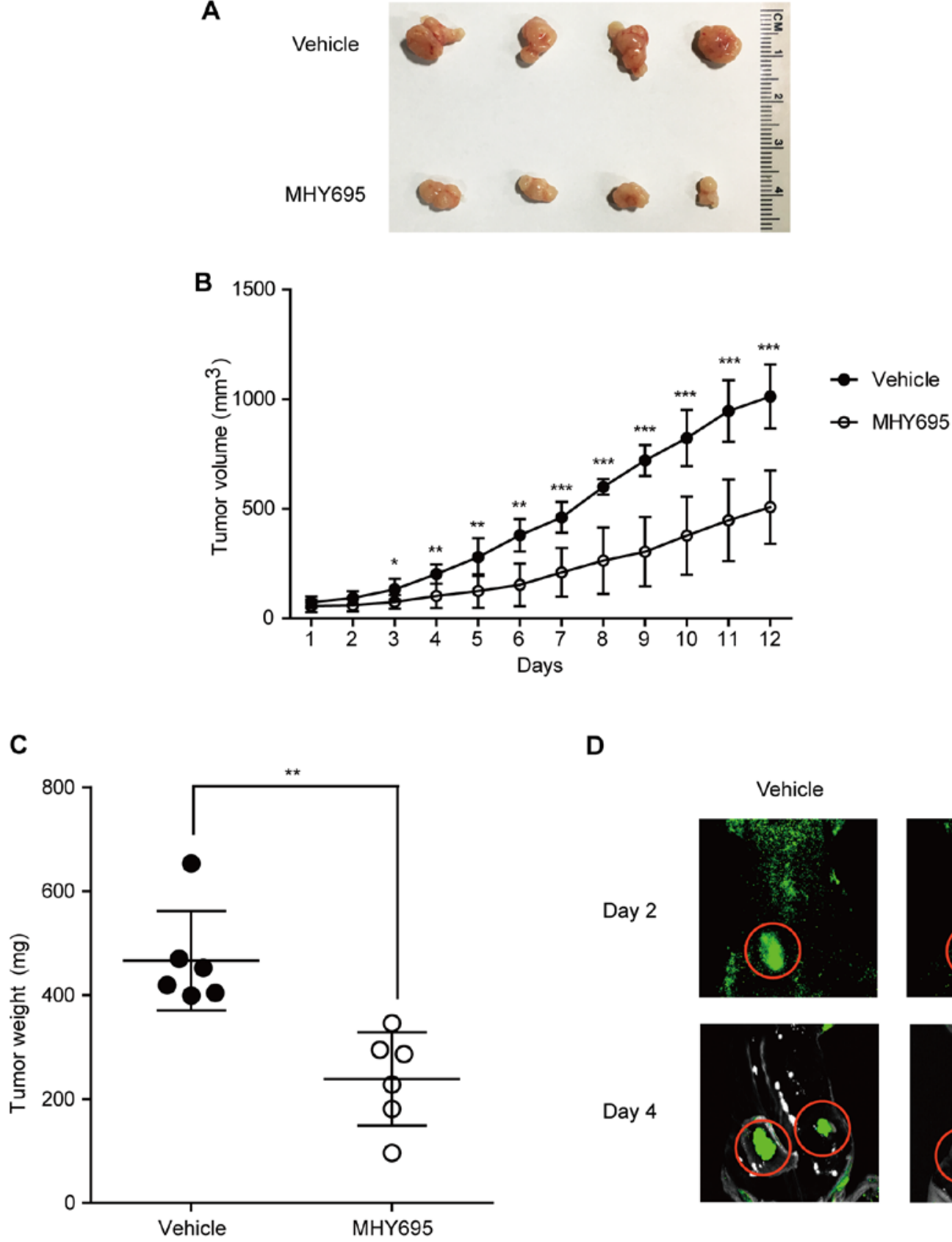

D

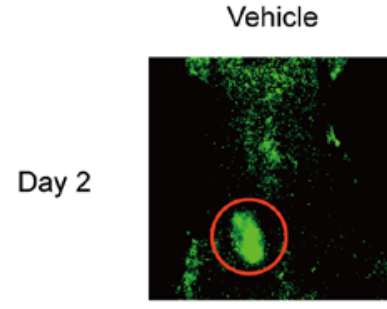

MHY695

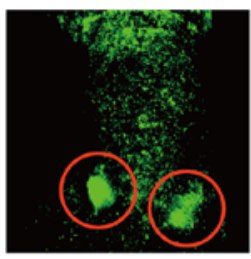

Day 4
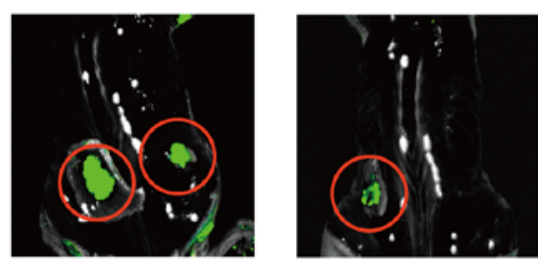

Figure 4. In vivo anti-cancer effects of MHY695 in a mouse xenograft model. (A) Tumors were resected from the mice following euthanasia. (B) Tumor size was measured daily with a caliper. Tumor volume $\left(\mathrm{mm}^{3}\right)$ was calculated as $\mathrm{L}^{2}$ x S x 0.5 . L, long diameter; S, short diameter. (C) Tumor weight was measured following resection. MHY695 $\left(2 \mathrm{mg} / \mathrm{kg}\right.$ ) was subcutaneously injected into each tumor daily. ${ }^{*} \mathrm{P}<0.05,{ }^{* *} \mathrm{P}<0.01$ and ${ }^{* * * *} \mathrm{P}<0.001$ vs. the vehicle-treated group. (D) In vivo anti-cancer effects of MHY695 (5 mg/kg) were visualized using GFP-tagged HCT116 stem cells. MHY695, (Z)-5-(3-ethoxy-4-hydroxybenzylide ne)-2-thioxothiazolidin-4-one.

Table I. $\mathrm{IC}_{50}$ of MHY695 in human colon cancer cells.

\begin{tabular}{lc}
\hline Cell line & $\mathrm{IC}_{50}(\mu \mathrm{M})$ \\
\hline HT-29 & 268.7 \\
NCM460 & 236.8 \\
Caco-2 & 110.2 \\
DLD-1 & 104.8 \\
HCT116 & 47.9 \\
\hline
\end{tabular}

MHY695,(Z)-5-(3-ethoxy-4-hydroxybenzylidene)-2-thioxothiazolidin4-one; $\mathrm{IC}_{50}$, half maximal inhibitory concentration.
Table II. Genetic features of human colon cancer cells.

\begin{tabular}{lcclcc}
\hline Cell line & KRAS & BRAF & \multicolumn{1}{c}{ PIK3CA } & PTEN & TP53 \\
\hline HT-29 & wt & V600E & P449T & wt & R273H \\
Caco-2 & wt & wt & wt & wt & E204X \\
DLD-1 & G13D & wt & E545K, D549N & wt & S241H \\
HCT116 & G13D & wt & H1047R & wt & wt \\
\hline
\end{tabular}

KRAS, GTPase KRas; BRAF, serine/threonine-protein kinase B-raf; PIK3CA, phosphatidylinositol 4,5-bisphosphate 3-kinase catalytic subunit $\alpha$ isoform; PTEN, phosphatase and tensin homolog; TP53, cellular tumor antigen p53; wt, wild-type. 




B
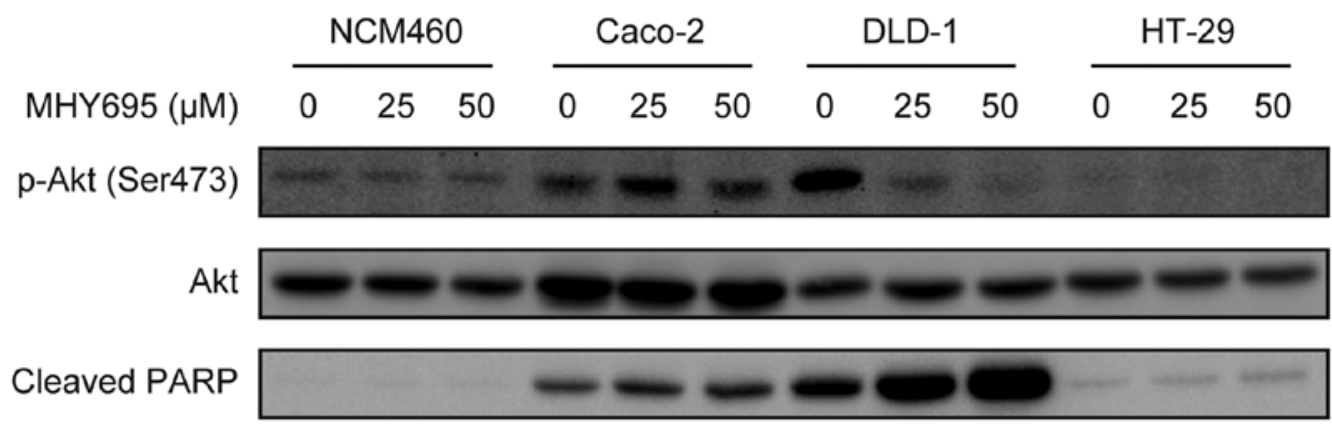

$\beta$-actin

C

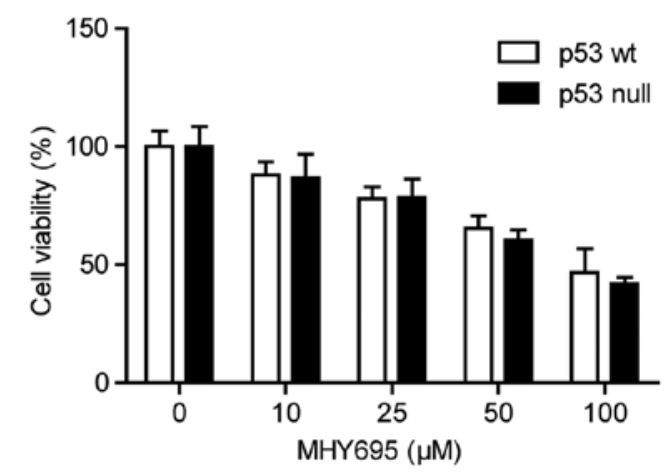

D

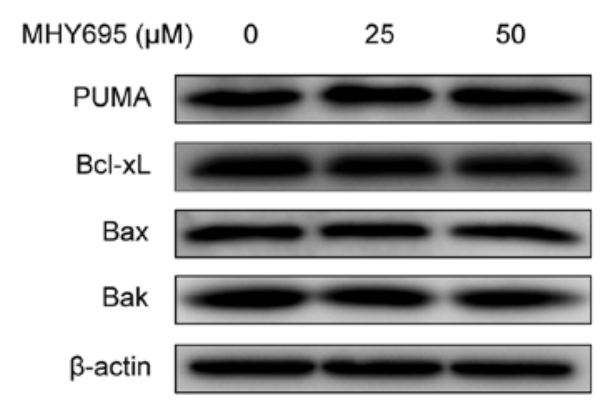

Figure 5. Cytotoxic effects of MHY695 are independent of p53. (A) NCM460, HT-29, Caco-2, DLD-1 and HCT116 cells were treated with various concentrations of MHY695. $\mathrm{P}<0.05,{ }^{* *} \mathrm{P}<0.01$ and ${ }^{* * *} \mathrm{P}<0.001$ vs. the vehicle-treated group. (B) Expression levels of phospho-Akt and cleaved PARP were investigated in NCM460, Caco-2, DLD-1 and HT-29 cells by western blot analysis. Cells were treated with vehicle or MHY695 (25 or $50 \mu \mathrm{M})$ for $24 \mathrm{~h}$. (C) Cell viability of p53 wt and p53 null HCT116 cells were investigated by MTT assay. p53 wt or p53 null HCT116 cells were treated with vehicle or MHY695 at the specified concentrations for $24 \mathrm{~h}$. (D) Downstream proteins of the p53-associated apoptosis pathway were investigated by western blot analysis. p53 wt HCT116 cells were treated with vehicle or MHY695 at the specified concentrations for $24 \mathrm{~h}$. MHY695, (Z)-5-(3-ethoxy-4-hydroxybenzylidene)-2-thioxothiazolidin-4-one; wt, wild-type; p-Akt, phospho-protein kinase B; PARP, poly(ADP-ribose) polymerase; PUMA, Bcl-2-binding component 3; Bax, Apoptosis regulator BAX; Bak, Bcl-2 homologous antagonist/killer.

resistance to chemotherapy. According to a previous study, p53 is mutated in Caco-2 (E204X), DLD-1 (S241F) and HT-29 (R273H) cells, but not in HCT116 cells (29). Thus, the effects of MHY695 were compared between p53 wt and null HCT116 cells. MHY695 showed equivalent cytotoxicity in both cell types. Also, PUMA, Bcl-xL, Bax and Bak, which are downstream proteins of p53, were not affected by MHY695 $(30,31)$. Collectively, these findings suggested that p53 was not associated with the cytotoxic effect of MHY695. The reasoning for the selectivity of MHY695 towards different types of cancer cell remains a future challenge.
When the results of MTT assays (Fig. 1B) were compared with those of Annexin V/PI staining (Fig. 2B), MHY695 appeared to exhibit lesser cytotoxicity during Annexin V/PI analysis. This result suggests that MHY695 may also promote cell cycle inhibition in HCT116 cells. Therefore, future studies using FACS analysis and/or immunoblot analysis of cell cycle proteins are warranted to determine whether MHY695 induces cell cycle arrest in other colon cancer cell lines.

The expression levels of numerous apoptosis-associated proteins were investigated using western blot analysis. Among them, Bax and Bak, which oligomerize in the mitochondrial 
membrane and form pores to facilitate the release of cytochrome C, were not affected by MHY695 treatment. Generally speaking, pro-apoptotic proteins such as Bax and Bak are upregulated in apoptotic cells (32). However, MHY695 significantly inhibited the phosphorylation of Akt and Bad. Also, caspase- 3 and PARP cleavage, reliable markers of apoptosis, were markedly apparent. According to Datta et al (8) reduced phosphorylation of Akt precedes Bad-induced cell death, hence it was concluded that MHY695 may induce apoptosis by influencing the phosphoinositide 3-kinase (PI3K)/Akt signaling pathway. Furthermore, as the PI3K/Akt pathway is primarily activated by growth factors, such as epidermal growth factor and fibroblast growth factor, it was suggested that MHY695 may target those growth factor receptors, the specifics of which present a future research objective $(33,34)$.

In addition to in vitro studies, the in vivo anti-cancer effects of MHY695 we investigated using a mouse xenograft model. Subcutaneous injection of MHY695 around the tumor significantly inhibited tumor growth compared with the vehicle. However, intraperitoneal injection of MHY695 did not inhibit the growth of tumors located in the flanks (data not shown). Therefore, the route of administration and optimal in vivo dose may be another focus of future research. Taken together, these findings suggested that MHY695 may constitute a candidate for the development of anti-cancer drugs against colon cancer.

\section{Acknowledgements}

Not applicable.

\section{Funding}

This work was supported by a 2-year research grant from Pusan National University (EI).

\section{Availability of data and materials}

The datasets used and/or analyzed during the current study are available from the corresponding author on reasonable request.

\section{Authors' contributions}

$\mathrm{GH}$ conducted and analyzed the in vitro cell based and animal experiments, and wrote the manuscript. DK, CP and HRM synthesized the chemical reagents. SJK, JC and YL conducted in vitro experiments. JWY, YJ, JL, NDK and HYC substantially contributed to the design of the study, interpreted the data, and wrote the manuscript. HRM and EI analyzed the data, conceived, supervised and directed the study, and wrote the manuscript. All the authors approved the final version of this manuscript and agreed to be accountable for all aspects of the work in ensuring that questions related to the accuracy or integrity of any part of the work are appropriately investigated and revised.

\section{Ethics approval and consent to participate}

All animal research and protocols were reviewed and approved by the Pusan National University Institutional Animal Care and Use Committee (PNU-IACUC).

\section{Patient consent for publication}

Not applicable.

\section{Competing interests}

The authors declare that they have no competing interests.

\section{References}

1. Siegel RL, Miller KD and Jemal A: Cancer Statistics, 2017. CA Cancer J Clin 67: 7-30, 2017.

2. Jung KW, Won YJ, Oh CM, Kong HJ, Lee DH, Lee KH and Community of Population-Based Regional Cancer Registries: Cancer Statistics in Korea: Incidence, mortality, survival, and prevalence in 2014. Cancer Res Treat 49: 292-305, 2017.

3. Benson AB III, Venook AP, Cederquist L, Chan E, Chen YJ, Cooper HS, Deming D, Engstrom PF, Enzinger PC, Fichera A, Grem JL, et al: Colon cancer, version 1.2017, NCCN clinical practice guidelines in oncology. J Natl Compr Canc Netw 15: 370-398, 2017.

4. Kerr JF, Wyllie AH and Currie AR: Apoptosis: A basic biological phenomenon with wide-ranging implications in tissue kinetics. Br J Cancer 26: 239-257, 1972.

5. Levin S, Bucci TJ, Cohen SM, Fix AS, Hardisty JF, LeGrand EK, Maronpot RR and Trump BF: The nomenclature of cell death: Recommendations of an ad hoc Committee of the society of toxicologic pathologists. Toxicol Pathol 27: 484-490, 1999.

6. Elmore S: Apoptosis: A review of programmed cell death. Toxicol Pathol 35: 495-516, 2007.

7. Li H, Zhu H, Xu CJ and Yuan J: Cleavage of BID by caspase- 8 mediates the mitochondrial damage in the Fas pathway of apoptosis. Cell 94: 491-501, 1998.

8. Datta SR, Dudek H, Tao X, Masters S, Fu H, Gotoh Y and Greenberg ME: Akt phosphorylation of BAD couples survival signals to the cell-intrinsic death machinery. Cell 91: 231-241, 1997.

9. Cai J, Yang J and Jones DP: Mitochondrial control of apoptosis: the role of cytochrome c. Biochim Biophys Acta 1366: 139-149, 1998.

10. Slee EA, Adrain C and Martin SJ: Executioner caspase-3, -6, and -7 perform distinct, non-redundant roles during the demolition phase of apoptosis. J Biol Chem 276: 7320-7326, 2001.

11. Choi PR, Kang YJ, Sung B, Kim JH, Moon HR, Chung HY, Kim SE, Park MI, Park SJ and Kim ND: MHY218-induced apoptotic cell death is enhanced by the inhibition of autophagy in AGS human gastric cancer cells. Int J Oncol 47: 563-572, 2015.

12. Jeon HS, Ahn MY, Park JH, Kim TH, Chun P, Kim WH, Kim J, Moon HR, Jung JH and Kim HS: Anticancer effects of the MHY218 novel hydroxamic acid-derived histone deacetylase inhibitor in human ovarian cancer cells. Int J Oncol 37: 419-428, 2010.

13. Kim MK, Kang YJ, Kim DH, Hossain MA, Jang JY, Lee SH, Yoon JH, Chun P, Moon HR, Kim HS, et al: A novel hydroxamic acid derivative, MHY218, induces apoptosis and cell cycle arrest through downregulation of NF- $\kappa \mathrm{B}$ in HCT116 human colon cancer cells. Int J Oncol 44: 256-264, 2014.

14. Park JH, Ahn MY, Kim TH, Yoon S, Kang KW, Lee J, Moon HR, Jung JH, Chung HY and Kim HS: A new synthetic HDAC inhibitor, MHY218, induces apoptosis or autophagy-related cell death in tamoxifen-resistant MCF-7 breast cancer cells. Invest New Drugs 30: 1887-1898, 2012.

15. De U, Kundu S, Patra N, Ahn MY, Ahn JH, Son JY, Yoon JH, Moon HR, Lee BM and Kim HS: A new histone deacetylase inhibitor, MHY219, inhibits the migration of human prostate cancer cells via HDAC1. Biomol Ther (Seoul) 23: 434-441, 2015.

16. Patra N, De U, Kim TH, Lee YJ, Ahn MY, Kim ND, Yoon JH, Choi WS, Moon HR, Lee BM and Kim HS: A novel histone deacetylase (HDAC) inhibitor MHY219 induces apoptosis via up-regulation of androgen receptor expression in human prostate cancer cells. Biomed Pharmacother 67: 407-415, 2013.

17. Lee SH, Kang YJ, Kim DH, Sung B, Kang JA, Chun P, Yoon JH, Moon HR, Kim HS, Chung HY and Kim ND: A novel oxiranylchromenone derivative, MHY336, induces apoptosis and cell cycle arrest via a p53- and p21-dependent pathway in HCT116 human colon cancer cells. Int J Oncol 44: 943-949, 2014. 
18. Patra N, De U, Kang JA, Kim JM, Ahn MY, Lee J, Jung JH, Chung HY, Moon HR and Kim HS: A novel epoxypropoxy flavonoid derivative and topoisomerase II inhibitor, MHY336, induces apoptosis in prostate cancer cells. Eur J Pharmacol 658: 98-107, 2011.

19. Yoon S, Kim JH, Lee YJ, Ahn MY, Choi G, Kim WK, Yang Z, Lee HJ, Moon HR and Kim HS: A novel carbazole derivative, MHY407, sensitizes cancer cells to doxorubicin-, etoposide-, and radiation treatment via DNA damage. Eur J Pharmacol 697: 24-31, 2012.

20. De U, Chun P, Choi WS, Lee BM, Kim ND, Moon HR, Jung JH and Kim HS: A novel anthracene derivative, MHY412, induces apoptosis in doxorubicin-resistant MCF-7/Adr human breast cancer cells through cell cycle arrest and downregulation of P-glycoprotein expression. Int J Oncol 44: 167-176, 2014.

21. Hwang HJ, Kang YJ, Hossain MA, Kim DH, Jang JY, Lee SH, Yoon JH, Moon HR, Kim HS, Chung HY and Kim ND: Novel dihydrobenzofuro[4,5-b][1,8]naphthyridin-6-one derivative, MHY-449, induces apoptosis and cell cycle arrest in HCT116 human colon cancer cells. Int J Oncol 41: 2057-2064, 2012.

22. Kim SH, Kang YJ, Sung B, Kim DH, Lim HS, Kim HR, Kim SJ, Yoon JH, Moon HR, Chung HY and Kim ND: MHY-449, a novel dihydrobenzofuro[4,5-b][1,8]naphthyridin-6-one derivative, mediates oxidative stress-induced apoptosis in AGS human gastric cancer cells. Oncol Rep 34: 288-294, 2015.

23. Lee SH, Kang YJ, Sung B, Kim DH, Lim HS, Kim HR, Kim SJ, Yoon JH, Moon HR, Chung HY and Kim ND: MHY-449, a novel dihydrobenzofuro[4,5-b][1,8] naphthyridin-6-one derivative, induces apoptotic cell death through modulation of Akt/FoxO1 and ERK signaling in PC3 human prostate cancer cells. Int J Oncol 44: 905-911, 2014.

24. Lim HS, Kang YJ, Sung B, Kim SH, Kim MJ, Kim HR, Kim SJ, Choi YH, Moon HR, Chung HY and Kim ND: Novel dihydrobenzofuro[4,5-b][1,8]naphthyridin-6-one derivative, MHY-449, induces cell cycle arrest and apoptosis via the downregulation of Akt in human lung cancer cells. Oncol Rep 34: $2431-2438,2015$

25. Jada SR, Matthews C, Saad MS, Hamzah AS, Lajis NH, Stevens MF and Stanslas J: Benzylidene derivatives of andrographolide inhibit growth of breast and colon cancer cells in vitro by inducing G(1) arrest and apoptosis. Br J Pharmacol 155: 641-654, 2008 .
26. Zuliani V, Carmi C, Rivara M, Fantini M, Lodola A, Vacondio F, Bordi F, Plazzi PV, Cavazzoni A, Galetti M, et al: 5-Benzylidene-hydantoins: Synthesis and antiproliferative activity on A549 lung cancer cell line. Eur J Med Chem 44: 3471-3479, 2009.

27. Yang X, Wang W, Qin JJ, Wang MH, Sharma H, Buolamwini JK, Wang $\mathrm{H}$ and Zhang R: JKA97, a novel benzylidene analog of harmine, exerts anti-cancer effects by inducing G1 arrest, apoptosis, and p53-independent up-regulation of p21. PLoS One 7: e34303, 2012.

28. Pinson JA, Schmidt-Kittler O, Zhu J, Jennings IG, Kinzler KW, Vogelstein B, Chalmers DK and Thompson PE: Thiazolidinedione-based PI3K $\alpha$ inhibitors: An analysis of biochemical and virtual screening methods. Chem Med Chem 6: 514-522, 2011.

29. Ahmed D, Eide PW, Eilertsen IA, Danielsen SA, Eknæs M, Hektoen M, Lind GE and Lothe RA: Epigenetic and genetic features of 24 colon cancer cell lines. Oncogenesis 2: e71, 2013.

30. Nakano K and Vousden KH: PUMA, a novel proapoptotic gene, is induced by p53. Mol Cell 7: 683-694, 2001.

31. Ashkenazi A: Directing cancer cells to self-destruct with pro-apoptotic receptor agonists. Nat Rev Drug Discov 7: 1001-1012, 2008.

32. Wei MC, Zong WX, Cheng EH, Lindsten T, Panoutsakopoulou V, Ross AJ, Roth KA, MacGregor GR, Thompson CB and Korsmeyer SJ: Proapoptotic BAX and BAK: A requisite gateway to mitochondrial dysfunction and death. Science 292: 727-730, 2001.

33. Wang X, McCullough KD, Franke TF and Holbrook NJ: Epidermal growth factor receptor-dependent Akt activation by oxidative stress enhances cell survival. J Biol Chem 275: 14624-14631, 2000.

34. Hu Y, Lu H, Zhang J, Chen J, Chai Z and Zhang J: Essential role of AKT in tumor cells addicted to FGFR. Anticancer Drugs 25: 183-188, 2014.

This work is licensed under a Creative Commons Attribution-NonCommercial-NoDerivatives 4.0 International (CC BY-NC-ND 4.0) License. 